\title{
MEMORIAL
}

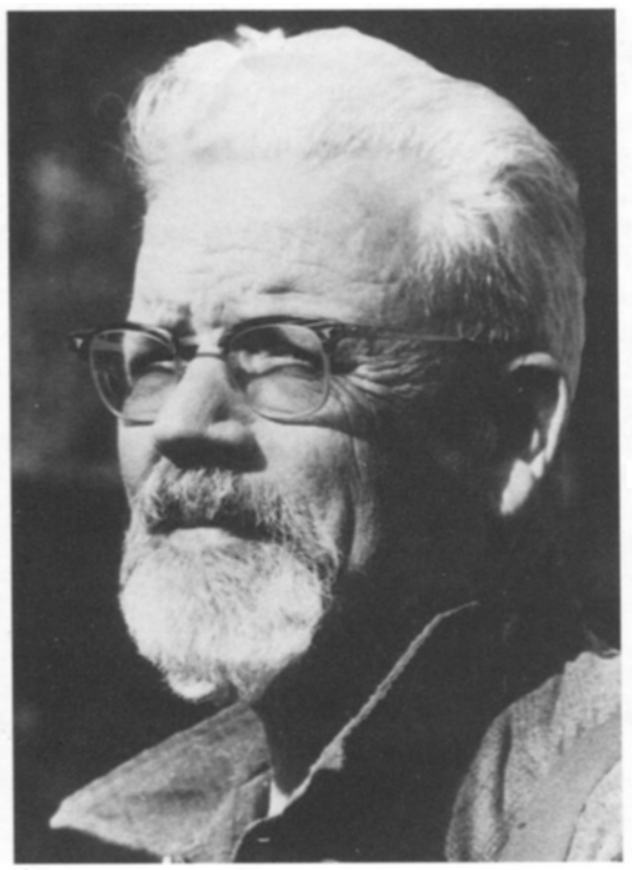

\section{J. WYATT DURHAM}

August 22, 1907-July 10, 1996

Wyatt Durham, as he invariably styled himself, died at Berkeley, California, in his 89 th year. He was born in a log cabin at Okanogan, Washington, the son of John Wyatt and Sarah Eveleyn Vandiver Durham. His father was a shipwright, who during several periods of his life, attempted dry-farming in eastern Washington. Wyatt spoke fondly and respectfully of his father and much of his quiet optimism and calm tolerance probably reflected his familial background. He married Jane Roberts on June 6, 1936, with whom he had a son, John Wyatt Durham. This marriage ended in divorce in 1971. In February, 1972, he married Jean Brower Firby on a very windy, cold day in the field in the White-Inyo Mountains of California. She survives.

Throughout his professional career, Wyatt Durham was a Paleontological Society activist. He was Vice President in 195253 and President in 1965-66. Durham's Presidential Address, The Incompleteness of Our Knowledge of the Fossil Record, was notable as one of relatively few presidential addresses devoted to previously unpublished research on a significant scientific question important to all paleontologists. As senior Co-Editor of the Journal of Paleontology from 1972 to 1976, with Joseph H. Peck, Wayne L. Fry, and W. A. Clements, Jr., Durham unselfishly labored at the principal "job" in the Society long after such work could have advanced his personal prestige. Throughout his career, he served the society; as an officer, Council Member, on several ad hoc committees, and reviewing journal manuscripts. Durham always confronted responsibilities seriously, thoroughly informed himself about the problem in hand, and was uniformly stable and fair-minded. He was especially cool-headed in the never-ending negotiations between the Society and the Society of Economic Paleontologists and Mineralogists during joint operation of the Journal of Paleontology. He was a calming, judicial presence in the somewhat virulent controversies surrounding establishment of our second journal, Paleobiology. The Society honored him with its medal in 1988. In 1993, his paper, "Observations on the Early Cambrian helicoplacoid echinoderms," won the award for the best paper of the year in the Journal of Paleontology.

Durham also was active in other professional groups; most notably the California Academy of Sciences where he was member of the Science Council from 1950 to 1956. He was Academy Trustee from 1959 to 1970, and President in 1966-1968. From 1966 through 1970 he was a member of the United States National Committee on Geology and in 1954-1955 and 19651966 was a member of the Galapagos International Science Project Expeditions. He was a Fellow of the Geological Society of America, the California Academy of Sciences, and the American Association for the Advancement of Science. He was a member of the Society of Economic Paleontologists and Mineralogists, American Association of Petroleum Geologists, Society of Systematic Zoologists, Paleontological Research Institution, the Paleontological Society (London), and the Japan Paleontological Society. He was a Correspondent of the Instituto Ecuatoriano de Ciencias Naturales. He held Guggenheim Fellowships in 1954-1955 and in 1965-1966.

Wyatt Durham is known for systematic study of Tertiary and Mesozoic corals, mollusks, and echnoids; and of late Precam- 
brian and early Paleozoic echinoderms. His extensive research on echinoids culminated in authorship of "A Classification of echinoids," with Richard Melville and five contributions to the Treatise on Invertebrate Paleontology. Beginning in the middle 1960 s, and continuing to his death, Durham devoted substantial effort collecting and studying Late Precambrian and Early Cambrian fossils. His description of the Helicoplacoidea, with Kenneth Caster was perhaps the most widely known result of this work.

During the 1940s through the 1960s, Durham was part of an active group of biostratigraphers centered at Berkeley, and including representatives from Stanford, UCLA, the California Division of Mines, and the University of Washington. This group meticulously, and often with vigorous debate, compared vertebrate, foraminiferal, and megainvertebrate zonal schemes for the West Coast Tertiary in light of newly developing biostratigraphic concepts. In addition, they correlated the West Coast succession with sequences in the Gulf Coast, Europe, and Asia. Finally, Durham contributed significantly to paleoclimatic and paleogeographic studies of the West Coast of North America and the Isthmian region. His 1985 contribution, "Movement of the Caribbean Plate and its importance to the biogeography in the Caribbean," was his final word on these problems and is a good example of his work. He was, however, engaged in similar studies including field work on the Late Cretaceous of the Arctic North Slope just before his death.

A high school general science teacher encouraged yoüng Wyatt Durham's interest in all aspects of natural history and communicated an interest in taxonomy. At that time, in his naturalistic rambles, he found a fossil, probably Buchia crassa, in glacial gravels at Seattle, which he later cited as the beginning of his interest in systematic paleontology. During his undergraduate years at the University of Washington (B. S., 1933) Charles Edwin Weaver became his mentor and lifelong professional friend and associate. He always remembered Weaver's method of introducing him to the world literature: Weaver would answer questions by giving a page number in a reference and telling young Wyatt to "look it up." Weaver sent Durham to the University of California at Berkeley to study under Bruce Clark, a man whom Durham valued for the rest of his life as a scientist and as a kindly, generous friend. While at Berkeley, Durham came into contact with Hubert Schenck at Stanford, who stimulated his first scientific paper on Operculina from the Tertiary of Washington. After completing his Master (1936), Durham was employed in Java and Sumatra in petroleum exploration until 1939, when he returned to Berkeley and Bruce Clark to complete his Ph.D. in 1941. From 1943 to 1946 he was Chief Paleontologist and Geologist for the Tropical Oil Company in Bogota, Colombia. In 1946-47 he served as an Associate Professor of Paleontology at the California Institute of Technology and, in 1947, along with Robert M. Kleinpell, he moved to the University of California, Berkeley, as Associate Professor of Paleontology and Curator of fossil Invertebrates. He remained for at Berkeley the rest of his life; he was promoted to Professor in 1953 and he retired as Professor Emeritus in 1975. He was Chairman of the Department of Paleontology from 1956 to 1957, and he was a Distinguished Visiting Scientist at the Universidad Nacional Autonoma de Mexico in 19781979, where he reorganized the paleontological collections and counseled the paleontological staff. He was a geologic and paleontologic consultant in California and Nevada, principally, from 1979 through 1995 . One gold prospecting project involved tracking paleostream channels in the Sierra Nevada in an area infested with marijuana plantations. Here he found it necessary to carry a pistol!

At Berkeley, Durham was part of an impressive array of paleontologists assembled after the Second World War. Durham, R. A. Stirton, Charles Camp, Ralph W. Chaney, and Robert M. Kleinpell, who among them, "covered" all major divisions of paleontology as construed at the time. Although personal relationships often were stormy, their professional efforts were complementary and of lasting scientific value. Durham advised more than 80 graduate students, of which 50 were doctoral candidates. W. K. Emerson, E. C. Allison, Warren Addicott, V. A. Zullo, Clifford Nelson, Carol Wagner, and D. B. Blake all were Durham doctorates. In addition, Joseph H. Peck remained with him as a Museum Paleontologist and was his "right hand" man.
R. L. Langenheim, Jr. Department of Geology University of Illinois at Urbana-Champaign 